tient), despite the fact that the risk of permanent disability in such patients is very low. ${ }^{2}$ These problems with the diagnostic criteria for multiple sclerosis and the entry criteria for clinical trials need to be addressed.

Annette Langer-Gould, M.D.

Scott W. Atlas, M.D.

Stanford University

Stanford, CA 94305-5405

annettel@stanford.edu
Daniel Pelletier, M.D.

University of California, San Francisco

San Francisco, CA 94143

Since publication of the article, Dr. Langer-Gould reports having received consulting fees from Genentech.

1. Kruit MC, van Buchem MA, Hofman PA, et al. Migraine as a risk factor for subclinical brain lesions. JAMA 2004;291:427-34.

2. Achiron $A$, Barak $Y$, Rotstein $Z$. Longitudinal disability curves for predicting the course of relapsing-remitting multiple sclerosis. Mult Scler 2003;9:486-91.

\title{
A Relapsing Inflammatory Syndrome and HHV-8
}

TO THE EDITOR: The case of human herpesvirus 8 (HHV-8) reported by Dagna et al. (July 14 issue) ${ }^{1}$ is considered to be distinct from HHV-8-associated multicentric Castleman's disease owing to the absence of typical histologic findings and elevated plasma levels of interleukin-6. The histopathology of HHV-8-associated multicentric Castleman's disease is variable, as compared with the classic descriptions of HHV-8-negative Castleman's disease ${ }^{2-4}$ and would encompass the changes described in the report, especially in the context of cytotoxic treatment before biopsy. In HHV-8-associated multicentric Castleman's disease, the HHV-8infected B-lineage cells can be seen either within the B-cell follicles or in the interstitium of many tissues, including bone marrow ${ }^{4,5}$ and lymph nodes, as seen in this case. Phenotypically, these cells resemble the plasmablasts in the follicles and the plasma cells in the interstitium. The infected cells secrete viral interleukin-6, which triggers an autocrine feedback loop involving human interleukin$6,{ }^{3}$ as reflected by the elevated plasma levels of interleukin-6, particularly at the time of the biopsy.

The downstream effects of interleukin- 6 are probably the cause of the clinical syndrome, which is indistinguishable from $\mathrm{HHV}-8$-associated multicentric Castleman's disease. We feel that this case report represents an HHV-8-associated multicentric Castleman's disease, rather than a newly recognized HHV-8-associated inflammatory syndrome.

Ahmet Dogan, M.D., Ph.D.

Mayo Clinic

Rochester, MN 55905

dogan.ahmet@mayo.edu

Ming-Qing Du, M.B., Ph.D.

University of Cambridge

Cambridge CB2 2QQ, United Kingdom
Peter G. Isaacson, M.B., Ch.B.

University College London Hospitals

London WClE 6JJ, United Kingdom

1. Dagna L, Broccolo F, Paties CT, at al. A relapsing inflammatory syndrome and active human herpesvirus 8 infection. N Engl J Med 2005;353:156-63.

2. Dupin N, Diss TL, Kellam P, et al. HHV-8 is associated with a plasmablastic variant of Castleman disease that is linked to HHV-8positive plasmablastic lymphoma. Blood 2000;95:1406-12.

3. Du MQ, Liu H, Diss TC, et al. Kaposi sarcoma-associated herpesvirus infects monotypic (IgM lambda) but polyclonal naive $\mathrm{B}$ cells in Castleman disease and associated lymphoproliferative disorders. Blood 2001;97:2130-6. [Erratum, Blood 2001;97:3678.]

4. Bacon CM, Miller RF, Noursadeghi M, McNamara C, Du MQ, Dogan A. Pathology of bone marrow in human herpes virus-8 (HHV8)-associated multicentric Castleman disease. Br J Haematol 2004;127:585-91.

5. Meggetto F, Cesarman E, Mourey L, Massip P, Delsol G, Brousset P. Detection and characterization of human herpesvirus-8-infected cells in bone marrow biopsies of human immunodeficiency viruspositive patients. Hum Pathol 2001;32:288-91.

THE AUTHORS REPLY: It seems to us that the issue raised by Dogan and colleagues is one of definition. From the clinical standpoint, severe symmetric arthrosynovitis (hardly ever observed in patients with HHV-8-associated multicentric Castleman's disease) was the referring symptom. Our patient had anemia of chronic inflammatory disease but none of the hematologic abnormalities and bone marrow features characteristically associated with HHV-8-associated multicentric Castleman's disease. ${ }^{1,2}$ On only two occasions was the level of human interleukin-6 increased; rather, it remained normal throughout the follow-up, regardless of disease activity. ${ }^{3}$ Although there is some variability in the features of Castleman's disease, some of which is apparently related to the HHV-8 infection, ${ }^{1,4}$ Castleman's disease remains primarily a morphologic diagnosis: a minimum set of criteria must be 
met or else the diagnosis ceases to have meaning. The microscopical appearance of the lymph nodes (including one excised before treatment) did not bear even a remote resemblance to any recognized type or variant of Castleman's disease. For these reasons, we do not believe that our patient should be given the diagnosis of Castleman's disease, but we do acknowledge the likelihood of a shared etiologic factor and pathogenesis.

Lorenzo Dagna, M.D.

Università Vita-Salute San Raffaele School of Medicine I-20132 Milan, Italy

lorenzo.dagna@hsr.it

Juan Rosai, M.D.

Centro Diagnostico Italiano

I-20147 Milan, Italy
Paolo Lusso, M.D., Ph.D.

San Raffaele Scientific Institute I-20132 Milan, Italy

1. Casper $\mathrm{C}$. The aetiology and management of Castleman disease at 50 years: translating pathophysiology to patient care. Br J Haematol 2005;129:3-17.

2. Bacon CM, Miller RF, Noursadeghi $M$, McNamara C, Du MQ, Dogan A. Pathology of bone marrow in human herpes virus- 8 (HHV8)-associated multicentric Castleman disease. Br J Haematol 2004;127:585-91.

3. Oksenhendler E, Carcelain G, Aoki Y, et al. High levels of human herpesvirus 8 viral load, human interleukin- 6 , interleukin10 , and $\mathrm{C}$ reactive protein correlate with exacerbation of multicentric Castleman disease in HIV-infected patients. Blood 2000;96: 2069-73.

4. Amin HM, Medeiros LJ, Manning JT, Jones D. Dissolution of the lymphoid follicle is a feature of the HHV8+ variant of plasma cell Castleman's disease. Am J Surg Pathol 2003;27:91-100.

\section{A Fractured Diagnosis}

TO THE EDItor: Cukierman et al., in their Clinical Problem-Solving article (Aug. 4 issue), ${ }^{1}$ affirm that "the clinical picture suggests primary Sjögren's syndrome because of the lack of clinical features associated with rheumatoid arthritis or other autoimmune disorders," according to the revised European criteria. ${ }^{2}$ The more recent American-European Consensus Group classification ${ }^{3}$ establishes as exclusion criteria for primary Sjögren's syndrome the presence of infection with hepatitis $\mathrm{C}$ virus (HCV) or the human immunodeficiency virus (HIV). Were HCV and HIV infection considered in this patient? Is there another fragment in the fractured diagnosis?

Francisco López-Medrano, M.D.

Manuel Lizasoain, M.D.

José María Aguado, M.D., Ph.D.

University Hospital 12 de Octubre

28041 Madrid, Spain

flmedrano@yahoo.es

1. Cukierman T, Gatt ME, Hiller N, Chajek-Shaul T. A fractured diagnosis. N Engl J Med 2005;353:509-14.

2. Vitali C, Bombardieri S, Moutsopoulos HM, et al. Preliminary criteria for the classification of Sjogren's syndrome: results of a prospective concerted action supported by the European Community. Arthritis Rheum 1993;36:340-7.

3. Vitali C, Bombardieri S, Jonsson R, et al. Classification criteria for Sjogren's syndrome: a revised version of the European criteria proposed by the American-European Consensus Group. Ann Rheum Dis 2002;61:554-8.

THE AUtHors REPLY: The revised American-European Consensus Group classification scheme requires that before the diagnosis of primary Sjögren's syndrome be made, the following conditions must be ruled out: infection with HCV or HIV, lymphoma, sarcoidosis, graft-versus-host disease, and the use of anticholinergic drugs.

Our patient was tested for HCV and HIV and was negative for both. Therefore, the diagnosis of primary Sjögren's syndrome is still plausible. Despite this fact, it is possible that longer follow-up might reveal another underlying diagnosis.

An increasing body of evidence supports a strong association between HCV infection and a Sjögren's syndrome-like condition. In one study, 12 percent of patients with Sjögren's syndrome were HCV-positive. ${ }^{1}$ In another study, 25.9 percent of people with chronic HCV infection met the European criteria for Sjögren's syndrome. ${ }^{2}$ Clinically, primary Sjögren's syndrome may be differentiated from Sjögren's syndrome associated with $\mathrm{HCV}$ infection by the absence of neuropathy, vasculitis, or liver involvement, as well as by the much higher frequency of antibodies to Ro and La. ${ }^{1}$

Tali Cukierman, M.D.

Nurith Hiller, M.D.

Tova Chajek-Shaul, M.D.

Hadassah-Hebrew University Medical Center, Mount Scopus Jerusalem 91240, Israel

chajek@hadassah.org.il

1. Ramos-Casals M, De Vita S, Tzioufas AG. Hepatitis C virus, Sjogren's syndrome and B-cell lymphoma: linking infection, autoimmunity and cancer. Autoimmun Rev 2005;4:8-15.

2. Nagao Y, Hanada S, Shishido S, et al. Incidence of Sjogren's syndrome in Japanese patients with hepatitis $\mathrm{C}$ virus infection. J Gastroenterol Hepatol 2003;18:258-66. 